\title{
DIRECTIONS OF DEVELOPMENT AND THE ROLE OF LOGISTICS IN POLISH ECONOMY
}

\author{
Bogdan Klepacki ${ }^{1}$, Professor, Barbara Kusto ${ }^{2}$, Ph.D. \\ ${ }^{1}$ Faculty of Economic Science, Warsaw University of Life Sciences; \\ ${ }^{2}$ Faculty of Law, Administration and Management, The Jan Kochanowski University in Kielce
}

\begin{abstract}
One of the most important sectors currently determining the economic situation of countries, regions, including rural areas, and businesses is logistics. The study shows the directions of changes in supplying Poland with the most important elements of logistic infrastructure, i.e. transport and stock infrastructure. It presents the position of logistics sector in the national economy measured by the share of transport, storage, information and communication activities against the background of industry, trade and construction sectors' activity in the creation of a net domestic product. The study also indicates the highly competitive position of Poland in logistics in comparison to other neighbouring countries and establishes that logistics can be an important factor in the country's development.
\end{abstract}

Key words: logistics, transport infrastructure, storage, Logistic Performance Index (LPI).

JEL code: 011,018

\section{Introduction}

In each historical period, there were elements influencing development processes in the economy and society. Science and its effects in the form of development of IT and usage of biological and market laws proved to be the driving force of the social and economic progress of the recent years. Nowadays, logistics is one of the most dynamically developing segments of the national economy. An increasing scale of flow of people, goods, financial capital and information can be observed. Elements of point infrastructure (ports, airports, railway junctions, railway and bus stations, warehouses, logistic centres etc.) and linear infrastructure (roads, railways, waterways, airways, pipelines etc.) are being expanded. This is of great importance for creating various logistic chains and reducing the costs of their operation in every industry. It contributes to the development of entire countries, including rural areas.

The aim of this study is to recognise the direction of changes in supplying Poland with the most important elements of logistic infrastructure (transport and stock infrastructure), the meaning of logistics in the economy, especially its role in creating gross national product and to indicate Poland's competitive position in comparison to its neighbouring countries.

Materials used for the study include information from the reporting of Central Statistical Office of Poland, Eurostat and World Bank data and the results of research available in the specialist literature on the subject. Both vertical and dynamic analysis (changes of studied values in time) and horizontal (international comparisons) were used.

\section{Reasons for development of logistics on a global scale}

Logistics is in most cases defined as a method for managing a supply chain, thus it includes planning, realisation and controlling an operational and effective flow of resources, production materials and finished products, as well as proper information from the point of origin to the point of consumption in order to satisfy the needs of a client. Logistics is also described as managing the processes of transporting goods and people, together with actions which support those processes in the systems in which they occur (Slownik..., 2006). The main objective of logistics is to minimise costs of transporting products in a supply chain, increasing a company's (chain's link) profit and preserving the standards of customer's service expected on the market, all at the same time. 
Logistic activities may include many stages (actions), such as: customer's service, demand prognosis, flow of information, stock control, manipulative activities, realisation of orders, reparative activities, supplying spare parts, locating production plants and warehouses, supply processes, packing, service of returns, waste management, transport activities and storage.

Every economic phenomenon, especially the ones reaching global scale, has many causes. A similar situation concerns logistics which, as an element of a human activity, has been functioning since ancient times. However, it used to have mainly a local dimension, but with a tendency to expand, mainly because of merchant, armed (war) or missionary voyages. Today, there are numerous reasons for this phenomenon, however the most significant ones include (Klepacki, 20140:

- savings reserves of costs in the area of production technology have already been depleted considerably;

- the offer for customers is continuously widened which is the result of a wide introduction of the marketing concept, i.e. offering customers whatever they wish, whenever they wish it and in what form,

- there has been a change in proportions in the scope of maintaining stocks between retailers and wholesalers and producers; producers and retailers want to stock as few products as possible,

- service providers and tradesmen minimise their storage activities by ordering goods only when providing services,

- transport costs have increased significantly, e.g. because of increasing prices of energy, thus traditional distribution systems have become too expensive;

- there has been a fast development of IT, which made it easier to register much data necessary in logistics such as location of customers, size of orders,

- there is a growing number of enterprises introducing advanced methods of organisation and production,

- companies' actions are becoming more globalised, which is connected with a growing competitiveness among producers and suppliers on a global scale.

\section{Significance of transport infrastructure in the social and economic development}

Transport infrastructure covers roads of all branches, transport points which include e.g. airports, ports etc., as well as a number of auxiliary devices. Transport infrastructure provides convenient conditions for transferring cargo and people. The most important tasks of the transport infrastructure include (Szymonik., 2013): satisfying the needs of societies and economies, realising tasks and activities formulated in transport policies, as well as shaping the past heritage. The most important functions fulfilled by the transport system include (Rydzkowski, Wojewodzka- Krol, 1997): consumption, production and integration.

Ensuring accessibility to transport infrastructure and to its proper capacity level enables the occurrence of so called diffusion of economic growth between regions (from well-developed regions to those still developing, particularly from agglomeration to rural, farming areas) (Zimny, 2016).

Building new infrastructure elements demonstrates both advantages and disadvantages. The former includes fast and safe transport and travelling for long geographical distances. An area supported by rich infrastructure is attractive for investors and tourists. New workplaces are being created and local residents have the possibility to search for jobs outside their place of residence. On the other hand, infrastructure may have a negative impact on the natural environment. Building 
new roads causes the necessity to allocate large amounts of land for it. Furthermore, fumes coming from various vehicles are also a threat, causing irreversible changes in the flora and fauna. Due to deforestation, animals lose their natural living conditions, plants are damaged. Topography of a given area, its landscape and the optimum level of soil water are changed and because of that accidents e.g. road accidents take place (Chrabaszcz, 2012).

\section{The status of the road network in Poland and in selected EU countries}

According to data of the Central Statistical Office (CSO), there were $420200 \mathrm{~km}$ of public roads in Poland in 2016. The majority of them were the municipal roads - $58.8 \%$, district roads constituted $29.7 \%$, voivodship roads $-6.9 \%$, while state roads had the smallest share in all the roads with $4.6 \%$ (Local Data Bank, CSO 2016). The length of public roads has been increasing steadily since then (Figure 1 ).

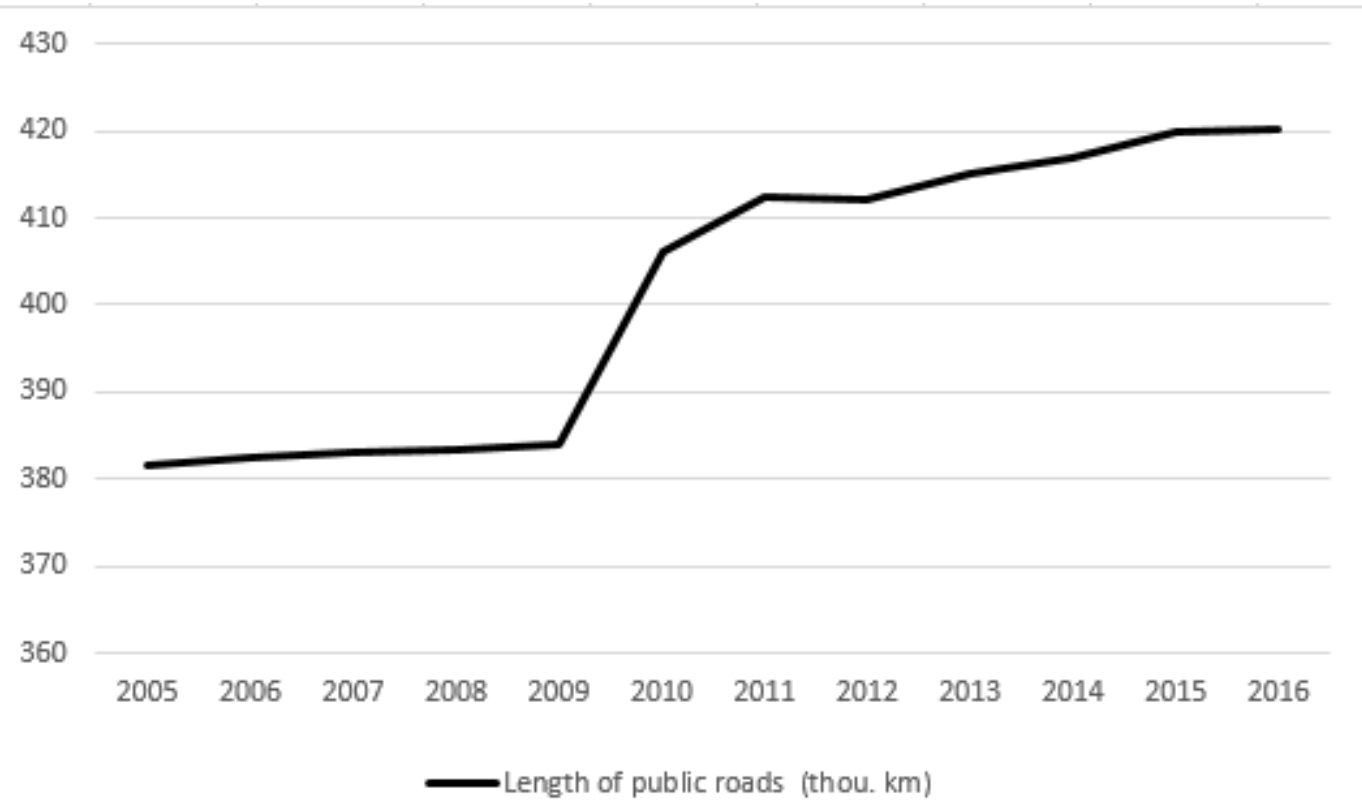

Source: Local Data Bank, CSO

Fig. 1. Length of public roads in Poland in the years 2010-2016

Motorways and expressways are categorised as state roads. At the end of 2016 there were $3.170,80 \mathrm{~km}$ of both motorways and expressways, out of which the former constituted $51.6 \%$ $(1.636,9 \mathrm{~km})$, and the latter $-48.4 \%$. In comparison to 2010 , the length of motorways increased by $90.9 \%$ and the length of expressways was extended by $127.3 \%$. On every $1000 \mathrm{~km}^{2}$ there was $10.1 \mathrm{~km}$ of expressways and motorways, i.e. $106.9 \%$ more than in 2010 (4.9 km). Most motorways and expressways were built in 2011 and 2012 due to the European Football Championship organised in Poland in 2012.

In terms of density of motorways, Poland's performance is poor in comparison to other EU countries. In 2016, there were $5.24 \mathrm{~km}$ of motorways per every $1000 \mathrm{~km}^{2}$. In the European Union, the highest indicators of motorways (per every $1000 \mathrm{~km}^{2}$ ) were recorded in the Netherlands - the number over 13 times bigger than the one concerning Poland $(66 \mathrm{~km})$ and Luxembourg $(58 \mathrm{~km})$. The lowest indicator was recorded in, among others, Estonia, Finland and Romania $-3 \mathrm{~km}$ per $1000 \mathrm{~km}^{2}$ (Picture 2). 


\section{Length of motorways $(\mathrm{km})$}

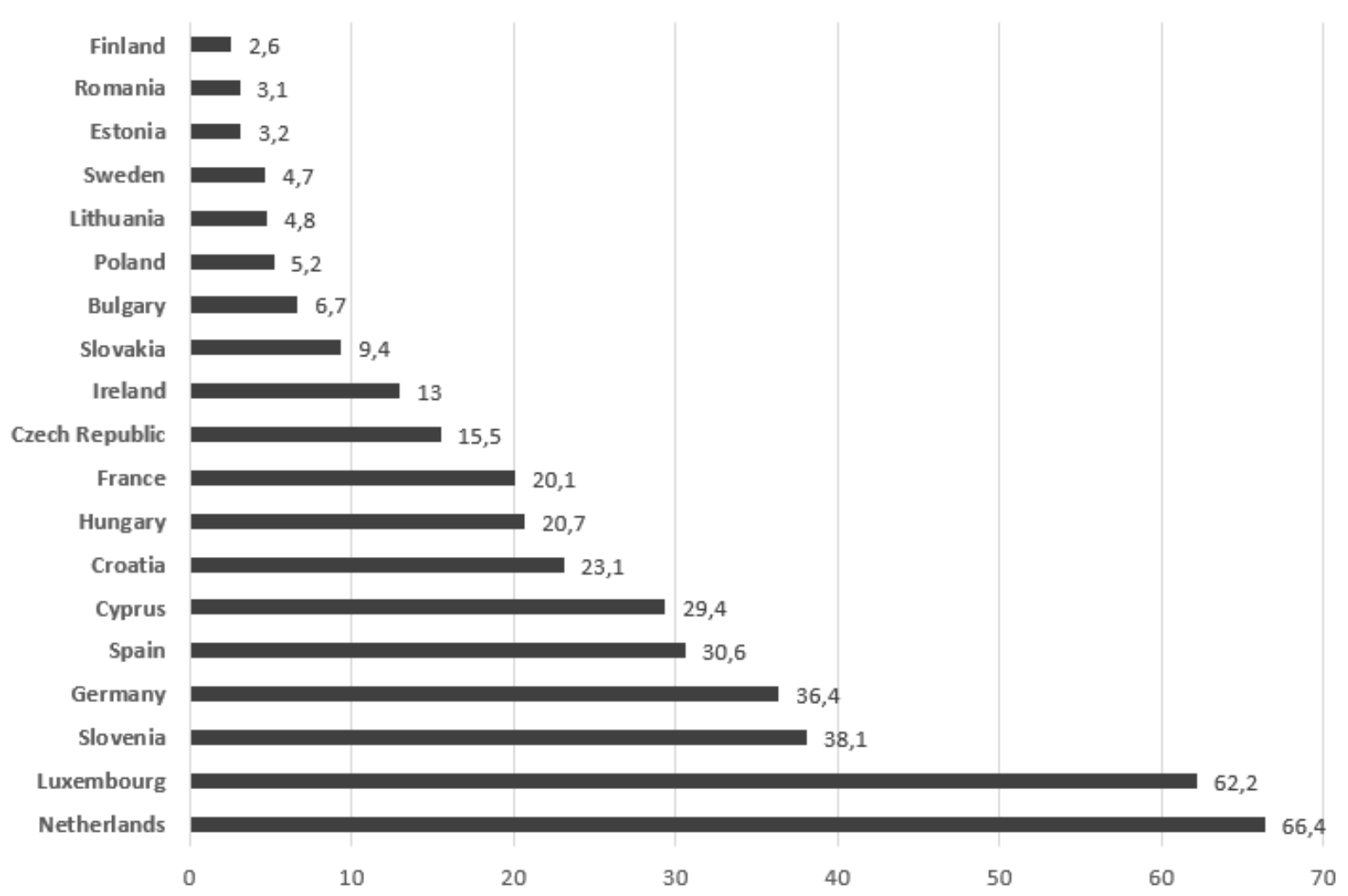

Source: authors' study on the basis of: Eurostat

http://appsso.eurostat.ec.europa.eu/nui/show.do?dataset=road_if_motorwa\&lang=en [access 21.06.2017]

\section{Fig. 2. Length of motorways in selected EU countries in 2016 calculated} by $1000 \mathrm{~km}^{2}$ of area

The following tendencies have occurred in Poland in the last decade in the scope of transportation:

1) in the railway transport, routes have been shortened, especially on less populated and poorly industrialised territories; on the other hand, usage of "major" routes have increased;

2) the velocity of road infrastructure development as a whole is low; a sort of positive aspect is the building of motorways and expressways;

3 ) the last decade has not brought any change in the scope of pipeline transport and inland water routes; 4. after the social and economic transformation in Poland (1989-1990) there was an economic breakdown of seaports and cargo shipping; today their steady growth is taking place;

4) air transport is clearly developing, although its position in the scope of mass shipping is still of a marginal character.

In general, it can be said that when it comes to transport infrastructure, Poland is less advanced than Western European countries. However, a significant progress is happening and in the near future, after completing the already started road and railroad investments, it will no longer be a barrier limiting the development of logistics and other economic activity.

\section{Changes in the storage economy}

The second most important element of logistics is warehousing. A warehouse is a separated closed accommodation, a space covered by a roof, an open outdoor landfill or a device for special purposes or a complex of such accommodations, spaces and devices, appropriately secured and equipped with devices designed for storing materials, semi-finished products and finished products. 
Storage market constitutes a part of the logistics market, being composed of three elements. The first one includes infrastructure: trade and industrial warehouses and other warehouses. The second element covers investments: warehouses for rent and warehouses for own purposes. The last element accounts for services: renting storage areas and providing storage services.

In the recent years, the Polish storage market has been developing dynamically. It concerns both the demand, as well as the supply. The supply of storage area available in Poland is presented in Figure 3. At the end of 2017 there was nearly 13.4 million $\mathrm{m}^{2}$ of storage area available (Olszewski, Mika, 2016), while in 2007 it was only 4,7 $\mathrm{mln} \mathrm{m}^{2}$. It proves the unusual increase in its supply and its dynamic development in Poland.

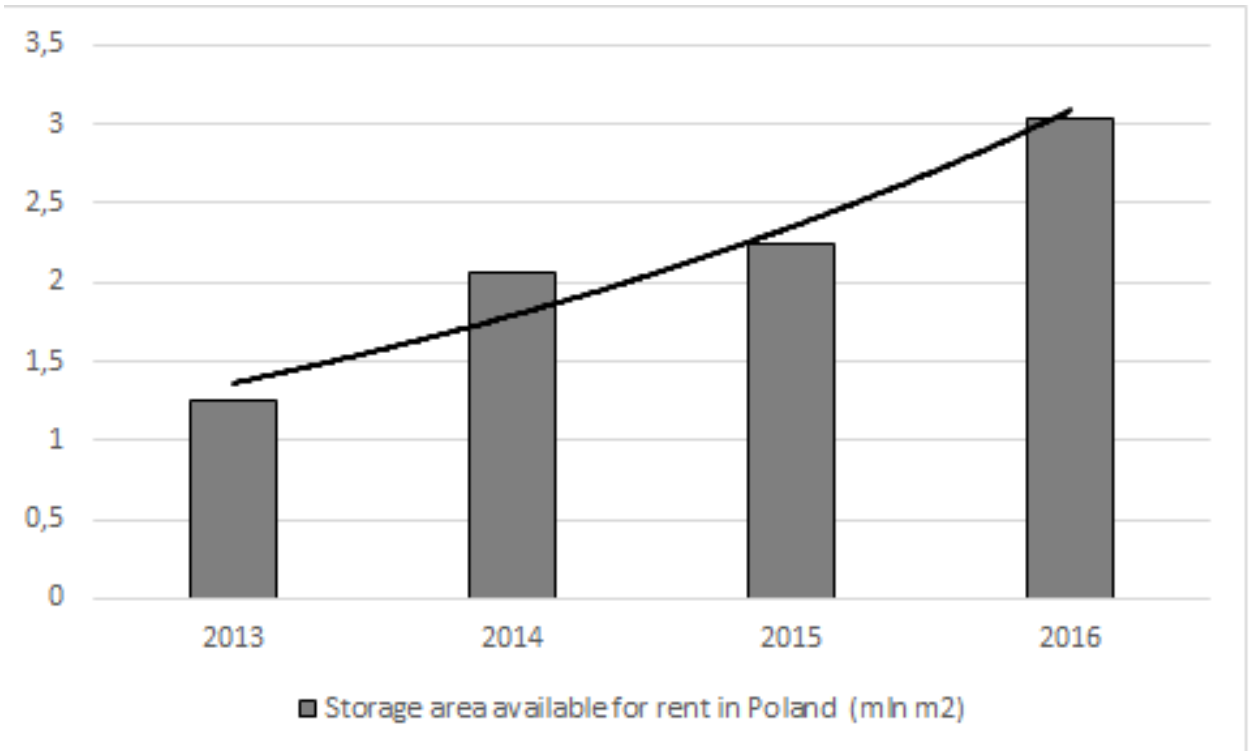

Source: authors' study on the basis: T. Olszewski, T. Mika, Rynek magazynowy w Polsce 2014, 2015,2016 [Storage market in Poland 2014, 2015, 2016]. Report: www.magazyny.pl, Warszawa 2016, p. 2 and T. Olszewski, T. Mika \&others., Rynek nieruchomosci magazynowych w Polsce w 2017 r.[Market of storage real estate assets in Poland in 2017], Report: www.magazyny.pl, 2017 p. 6.

\section{Fig. 3. Storage area available for rent in Poland in the years 2013-2016}

In terms of the regional section, the biggest demand for storage areas occurs in central Poland, in the region surrounding Warsaw, Upper Silesia, in Poznan and Wroclaw (Figure 4). Activity of investors and rent payers who decide on the location of warehouses depends mainly on the quality of transport infrastructure and economic potential of surrounding areas. Investors locate storage areas in the close vicinity of motorways and expressways. It can be stated that the tenants betting on the local markets choose the central part of Poland for their investments, meanwhile those who invest on a global scale - southern areas (Fechner, Szyszka 2014).

The warehouses in operation indicate various stages of technological advancement. A modern storage area is to be construed as an area located in a storage facility characterised by the following parameters (Logistyka w Polsce. Report 2009):

- storage height - minimum 9 metres;

- at least one gate per $1000 \mathrm{~m}^{2}$ of area;

- dust-free floor, with the minimum resistance of 5 tons $/ \mathrm{m}^{2}$;

- anti-fire system in the form of sprinklers and smoke dampers;

- 5-8 \% of office area. 


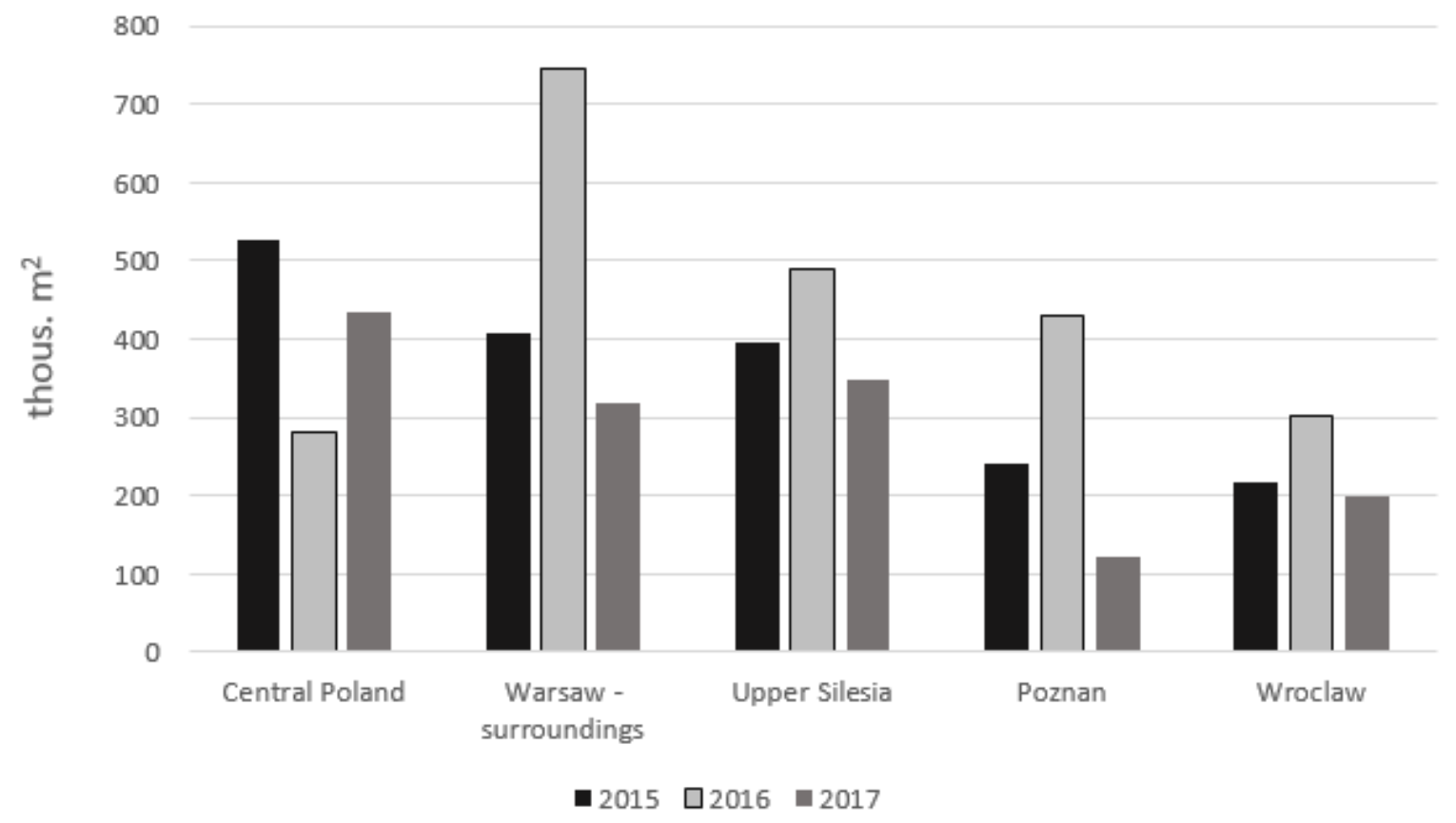

Source: authors' study on the basis: T. Olszewski, T. Mika, Rynek nieruchomości magazynowych w Polsce w 2016r. [Market of storage real estateassets in Poland in 2016], Report: www.magazyny.pl, 2016 and T. Olszewski, T. Mika, Rynek magazynowy w Polsce 2017.[Storage market in Poland 2017]. Report: www.magazyny.pl, Warszawa 2017.

Fig. 4. Location of main storage markets in Poland in the years 2015-2017

Modern storage area in Poland covered nearly 12 million $\mathrm{m}^{2}$ at the end of 2017 . Its stages in the years 2001-2017 are presented in Figure 5.

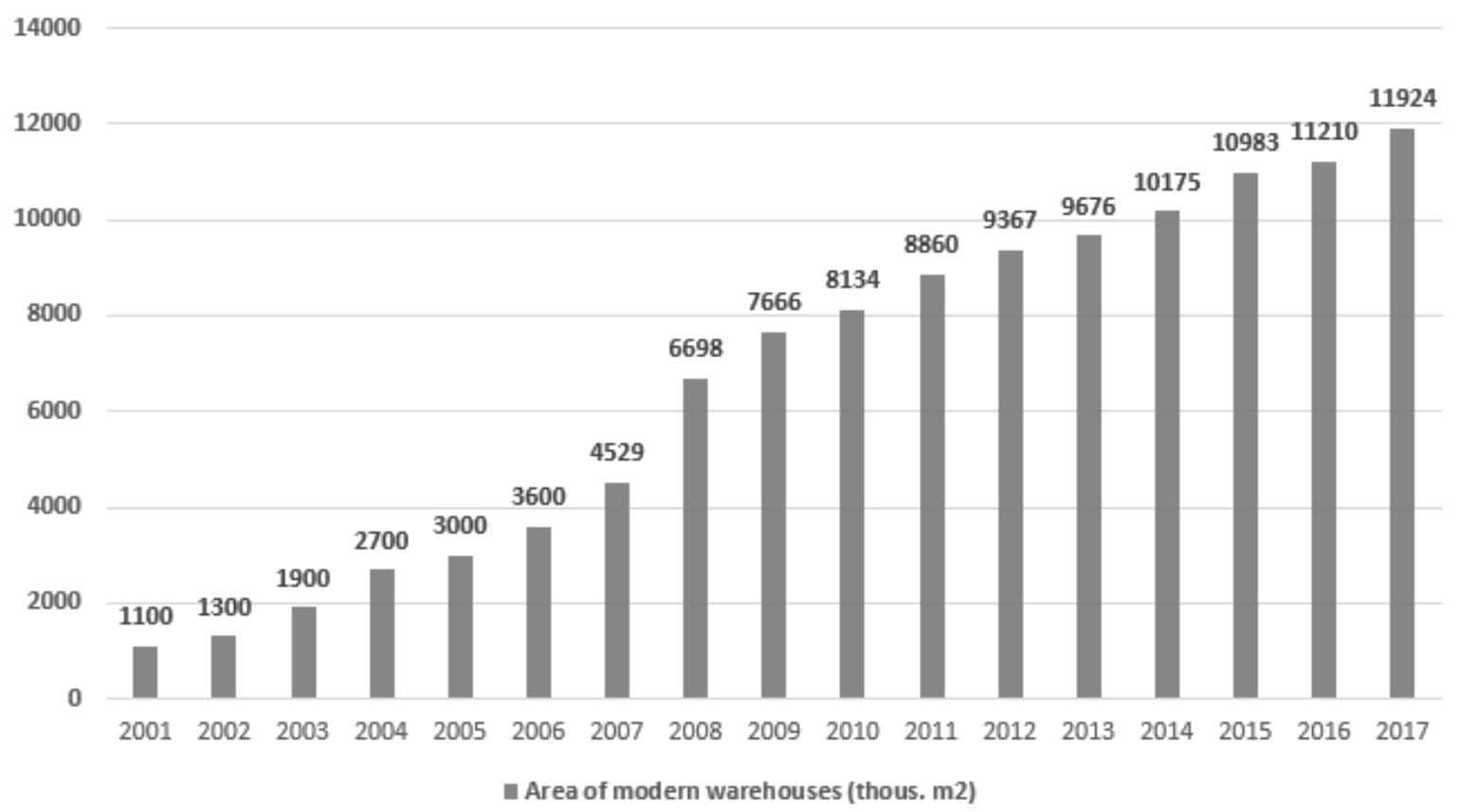

Source: Logistics in Poland. Reports 2007, 2009. Biblioteka Logistyka. Poznan, Statistical Yearbooks of Central Statistical Office 2002-2016, data of CSO

\section{Fig. 5. Area of modern warehouses in the years 2001-2017 in thousand $\mathbf{m}^{2}$}

A significant progress has occurred in terms of modern storage area. In the period of the last 16 years, it has expanded its surface nearly ten times. Important fact is that this surface increased every year without any downfall periods, being mainly realised by international companies. This leads to the conclusion that Poland's position as an attractive place for locating logistic investments has been moving upwards. 


\section{Economic significance of logistics in the Polish economy}

Significance of particular sectors in the national economy can be measured in various manners. Most often it is their input in generating the Gross Domestic Product (GDP) that is taken into account. In 2015 selected sectors participated in the GDP structure in the following shares (in \%):

- industry

- car sales and repair

- building industry

- transport and storage economy - 5.8

- IT and communication
$-23.5$

$-15.4$

$-6.3$

Classifying purely logistic sectors (transport, storage economy, IT, communication) as elements of logistics, it can be stated that they have generated $9.4 \%$ GDP. However, logistics is not recognised in complete separation in statistical data. It constitutes a considerable part of trade and industrial activities, as well as many other activities. Solely by adding car sales and repairs to the above value, the result increases to nearly $25 \%$. Thus, it can be assumed that logistic activity generates at least every forth unit of GDP in the national economy.

Logistics is also crucial for employment ratings. The general employment rate, which equalled 15.4 million people in 2015, comprised of $5.3 \%$ of them working in the transport and storage economy sector and $2.2 \%$ working in the IT and communication sector. Logistics also engaged $15.5 \%$ of all fixed assets (transport and storage economy - $12.7 \%$, IT and communication $2.8 \%$ ). Logistics is also characterised by higher working efficiency - every person employed in transport and storage economy scored $110.5 \%$ of GDP (of total national average value), meanwhile IT and communication generated $163.8 \%$ per employee.

\section{Competitive position of the Polish Logistics in terms of selected neighbouring countries}

The level of competitiveness of logistic companies can be measured in various manners. The most frequently used method is called Logistics Performance Index (LPI). It is calculated for 163 countries. LPI is measured by taking into account six characteristics, that is:

1) efficiency of the clearance process by order control agencies, including customs,

2) quality of trade and transport related infrastructure,

3) easy of arranging competitively priced shipments,

4) competence and quality of logistic services,

5) ability to track and trace consignments,

6) timeless of shipments in reaching destination within a schedule or expected delivery time.

Table 1 presents Poland's position in comparison to its neighbouring countries, by assessing situations from 2007, 2010, 2012, 2014 and 2016.

By taking LPI into consideration, it can be assumed that Poland is relatively well prepared for providing logistic services. Although its assessment is worse than the one of Germany, which is the world's logistic leader, on the regional scale it is located on the level similar to the one of its neighbours. In comparison to 2007, a significant progress has been made up to this day, pushing Poland up to $30^{\text {th }}$ position from $40^{\text {th }}$ in the world ranking. However, this position has dropped to $33^{\text {rd }}$ in the recent period. It means that Polish logistic companies are capable of adjusting themselves to actual requirements of clients, even though they do this a little slower than companies in a few neighbouring countries. 


\section{Competitive position of the Polish logistics in comparison to selected Central Europe countries in the years 2007-2016}

\begin{tabular}{|l|c|c|c|c|c|c|}
\hline \multirow{2}{*}{ Country } & \multicolumn{5}{|c|}{ LPI by year } & $\begin{array}{c}\text { Position in the } \\
\text { global ranking } \\
\text { in 2016 }\end{array}$ \\
\cline { 2 - 7 } & $\mathbf{2 0 0 7}$ & $\mathbf{2 0 1 0}$ & $\mathbf{2 0 1 2}$ & $\mathbf{2 0 1 4}$ & $\mathbf{2 0 1 6}$ & $\begin{array}{c}\text { 2016 } \\
\text { Poland }\end{array}$ \\
\hline Germany & 4.04 & 3.44 & 3.43 & 3.49 & 3.43 & 1 \\
\hline Czech Rep. & 3.13 & 4.11 & 4.03 & 4.12 & 4.23 & 26 \\
\hline Slovakia & 2.92 & 3.24 & 3.03 & 3.25 & 3.34 & 41 \\
\hline Ukraine & 2.55 & 2.57 & 2.85 & 2.98 & 2.74 & 80 \\
\hline Lithuania & 2.78 & 3.13 & 2.95 & 3.18 & 3.63 & 29 \\
\hline Hungary & 3.15 & 2.99 & 3.17 & 3.46 & 3.43 & 31 \\
\hline Latvia & 3.02 & 3.25 & 2.78 & 3.40 & 3.33 & 43 \\
\hline
\end{tabular}

Source: Arvis J.F., Mustra M.A., Panzer J., Ojala L., Naula T., 2007: Connecting to Competence. Trade Logistics in the Global Economy. The Logistics Performance Index and Its Indicators. The International Bank for Reconstruction and Development. The World Bank, Washington and Logistic Performance Index (LPI). $2010,2016$. http://web.worldbank.org/

\section{Conclusions}

1) Poland is an important region for providing logistic services. The international exchange rate is growing e.g. due to its central location in Europe. Poland's accession to the European Union in 2004 offered a possibility to overcome economic barriers which had been hindering infrastructural investments similar to those realised in other EU countries. It means that the condition of the Polish logistics will be an important factor in the country's development, both on the macroeconomic and local levels. Infrastructure development is a factor influencing location of industrial and service facilities, especially logistic centres which can be a determinant for activation of rural areas, provide jobs and be a source of income for the population.

2) Polish logistic companies are developing fast, the area of modern warehouses is increasing. Companies are improving their offers which then boosts their international competitiveness. Logistics activity is becoming a sort of Polish specialty increasingly affecting GDP and the state of national economy.

3) Central Europe is becoming one of the most important regions in terms of logistics development. That is due to geographical location and the fact that Central European countries became members of the European Union, but also because of the anticipated development of the Eastern European countries - the former members of the Soviet Union.

\section{Bibliography}

1. Arvis, J.F., Mustra, M.A., Panzer, J., Ojala, L. and Naula, T. (2007). Connecting to Competence. Trade Logistics in the Global Economy. The Logistics Performance Index and Its Indicators. The International Bank for Reconstruction and Development. Washington: The World Bank.

2. Bank Danych Lokalnych, (2018). Bank Danych Lokalnych. [online] Available at: https://bdl.stat.gov.pl/BDL/start\# (Accessed 28 Mar. 2018)

3. Chrabaszcz, K. (2012). Cechy regionalne a rozwoj krajowej infrastruktury drogowej na przykladzie autostrady A4. T 20, No. 1. [pdf] Tarnow: Zeszyty Naukowe Malopolskiej Szkoly Ekonomicznej w Tarnowie. Available at: http://zn.mwse.edu.pl/ebooki/20/39-47.pdf (Accessed 20 June 2017).

4. Eurostat (2018). Length of Motorways and E-roads. [online] Available at: http://appsso.eurostat.ec.europa.eu/nui/show.do?dataset=road_if_motorwa\&lan \%C2 \%A0=en (Accessed 21 June. 2017)

5. Fechner, I. and Szyszka, G., (red.) (2014) Logistyka w Polsce. Raport 2013. Poznan: Biblioteka Logistyka.

6. Fertsch, M. (red.) (2006). Slownik terminologii logistycznej. Poznan: Instytut Logistyki i Magazynowania.

7. Klepacki, B. (2014). Concept and Importance of Agrologistics for Development of Agribusiness. Conference: Carpathian Logistics Congress (CLC): Cracow, DEC 09-11, 2013 . VSB Tech Univ Ostrava; Technical Univ Kosice; TANGER Ltd. pp: 14-17. 
8. The World Bank, (2018). Logistic Performance Index (LPI). 2010. 2016. [online] Available at: http://web.worldbank.org/ (Accessed: 28 Mar. 2018)

9. Logistyka w Polsce. Raport 2007. 2009. (2009, 2010) Poznan: Biblioteka Logistyka.

10. Mierzwiak, B. and Klepacki, B. (2018). Rekordowe wyniki rynku magazynowego w Polsce poczatek czy koniec dynamicznego rozwoju. Retail Summit, Warsaw, 13.03.2017. pp. 1

11. Olszewski, T, Mika, T. (2016). Rynek powierzchni magazynowych w Polsce 2016. Raport. Warszawa: www.magazyny.pl, p. 2.

12. Olszewski, T. and Mika, T. (2017) Rynek nieruchomości magazynowych w Polsce w 2015r. Raport: www.magazyny.pl, 2016 p.

13. Roczniki Statystyczne Rzeczypospolitej Polskiej 2006, 2010, 2016 Warszawa.

14. Rokicki, T. (2014). Organizacja i ekonomika transportu. Warszawa: Wydawnictwo SGGW.

15. Rydzkowski, W. and Wojewodzka-Krol, K. (red) (1997). Transport. Warszawa: PWN.

16. Szymonik, A. (2013). Ekonomika transportu dla potrzeb logistyka (I) Teoria i Praktyka. Warszawa: Wydawnictwo Diffin.

17. Zimny, A. (2016). Wskazniki rozwoju transportu w ogolnopolskich i regionalnych dokumentach strategicznych [in:] Vol. 2. Konin: Koninskie Studia Spoleczno-Ekonomiczne. Available at: http://ksse.pwsz.konin.edu.pl/wp-content/uploads/2017/03/KSSE-23.final_.pdf. 